\title{
ADEQUATE CALCIUM NUTRITION AND QUALITY OF EGG SHELL AND BONES IN LAYERS - INNOVATIVE APPROACH
}

\author{
M. Lukić, Z. Pavlovski, Z. Škrbić \\ Institute for Animal Husbandry, Autoput 16, P. Box 23, 11080 Belgrade-Zemun, Republic of Serbia \\ Corresponding author: miloslukic.izs@gmail.com \\ Invited paper
}

\begin{abstract}
Calcium metabolism (Ca) in layers depends on many factors which can be divided into factors influencing the intake, absorption, retention and/or excretion of Ca. Varying of any of above mentioned factors presented and reviewed in this study, exhibit their impact on quality of bones in layers and egg shell quality. For the purpose of maintaining of the egg quality and quality of layer hens' bones, the influence of mentioned factors on production should be taken into consideration in the practice, and on that basis not only the proper diet $\mathrm{Ca}$ level determined, but also adequate source and size of $\mathrm{Ca}$ particles, as well as mutual balance with other nutrients in the diet, primarily phosphorus, vitamin D and some micro elements. Recent studies have the direction of finding the more complex approach to solving of the issues of egg shell quality, also bone quality and ensuring adequate nutrition for modern layer hybrids.
\end{abstract}

Key words: calcium, laying hens, bones, product quality

\section{Introduction}

Egg shell quality and osteoporosis are permanent and significant problems in egg production. In practice, these problems are always associated with adequate nutrition of layers with calcium $(\mathrm{Ca})$, where primarily the adequate $\mathrm{Ca}$ level in diets is monitored.

However, previous multi-decade studies in this practically and economically very important field of layer nutrition, and especially more recent studies, indicate that adequate provision of calcium in nutrition of laying hens is actually considerably more complex issue and requires broader approach (Lukić et al., 2009a). Nutrition of layers with calcium requires monitoring and control of multiple factors and nutrients in order to ensure adequate calcium level, as the main component in preservation of the egg shell quality and bone quality, in the body of contemporary high productive hybrids. Therefore, in nutrition of layers it is 
necessary to permanently revise their Ca requirements, also to certain extent, their phosphorus and vitamin D requirements, and adjust them with the latest scientific findings in this field, as well as concrete production conditions.

The present study gives the brief review of some of the research results relating primarily to $\mathrm{Ca}$ in layers, as well as certain practical changes in the layer nutrition in this and other nutrients which are recommended according to previous scientific findings.

\section{Ca in diet, bones and egg shell}

In general, it can be said that the calcium metabolism depends on series of factors which can be divided into those influencing the intake, absorption, retention and/or excretion of calcium in layers.

The intake (consumption) of calcium depends first of all on the amount of food the layer is able to take/consume, i.e. the appetite of layers and the calcium level in the diet. The layers' appetite depends on their age, environment temperature, amount of energy and protein in the diet, feeding time and feeding manner, but also concentration of the calcium in the diet (Taher et al., 1984; Roland, 1986a; Zhang and Coon, 1997; Roland and Bryant, 2000).

Obviously, intake is the first limiting factor in meeting of the $\mathrm{Ca}$ requirements of layers. So, Roland and Bryant (2000) suggest to formulate the diet based firstly on the daily $\mathrm{Ca}$ requirements following the consumption of food and mass of laid eggs, rather than to proceed according to recommendations expressed sole as the required level of diet $\mathrm{Ca}$.

Absorption of calcium mainly occurs in upper part of the small intestine, duodenum and upper part of the jejunum (Hurwitz and Bar 1965; Roland et al., 1972). Layers satisfy their higher requirements in calcium primarily by increasing the intestinal absorption, through an adaptive mechanism of change in the vitamin $\mathrm{D}$ metabolism, i.e. increasing the synthesis of $1,25(\mathrm{OH})_{2} \mathrm{D}_{3}$ as the strongest stimulator of Ca absorption (Soares, 1984).

Absorption of $\mathrm{Ca}$ depends on numerous factors, among which the most important are the physiological condition of the organism and stage of the ovulatory cycle, level of $\mathrm{Ca}$, of phosphorus, vitamin $\mathrm{D}$ and antinutritional substances in the food, intensity of egg production, as well as source and particle size of the Ca source (Reid and Weber, 1976; Ameenuddin et al., 1985; Roland, 1986a; Roland, 1986b; Keshavarz, 2003). Therefore, it is understandable that the digestibility of diet $\mathrm{Ca}$ in layers can vary significantly, but in practice, as stated by Hunton (2001), the best that can be expected is 50-60\% used Ca from the diet.

Retention (resorption) of $\mathrm{Ca}$ is done primarily through bone mineralization and therefore it can efficiently be assessed by measuring of the bone characteristics. The process of $\mathrm{Ca}$ retention is especially interesting and complex in 
layers, considering the exceptional dynamics and scope of the $\mathrm{Ca}$ flow in the organism and unique presence of medullar bone responsible for providing $\mathrm{Ca}$ in the time of egg shell calcification $(25-40 \% \mathrm{Ca}$ in egg shell of each egg derives from the medullar bone), and especially when food as a primary source of $\mathrm{Ca}$ for calcification is not present in the digestive tract (Leach, 2000; Whitehead 2004; Silversides et al., 2006). In short, in layers which have reached the sexual maturity the efficiency of the dietary $\mathrm{Ca}$ utilization increases, a deposit of $\mathrm{Ca}$ in body in form of medullar bone is created and uterus becomes capable of excretion of $\mathrm{Ca}$ in the amount over $100 \mathrm{mg} / \mathrm{h}$, which together represents unique physiological mechanism of the layer organism ensuring high amounts of Ca (even up to $10 \%$ of total amount of $\mathrm{Ca}$ in the organism) necessary for egg shell calcification in relatively brief time (egg shell is formed in the average in 20 hours).

$\mathrm{Ca}$ deficit, whether short term (e.g. over night during egg shell formation) or long term (during one part of entire production cycle), as a consequence has increased need for $\mathrm{Ca}$ from the bone depots in order to maintain normal production of eggs, which can reflect negatively on the quality of bones, depending on the level and duration of deficit. Lukić et al. (2010), in a three week trail with moderate $\mathrm{Ca}$ deficit in combination with substitution of certain \% of lime with marble particles in diets for young layers, followed by three week normalization of $\mathrm{Ca}$ nutrition of layers, established certain effect of applied treatments on bone quality. The effect depended on the bone that was studied, applied Ca deficit and \% of granulated marble in the diet for layers, and results indicated that three week nutrition of layers with $2.5 \%$ of $\mathrm{Ca}$ expressed the tendency towards long term adverse effect on the firmness of studied bones, and that the use of marble granules/particles in layer nutrition had positive effect on preservation of the bone firmness (Graph 1).
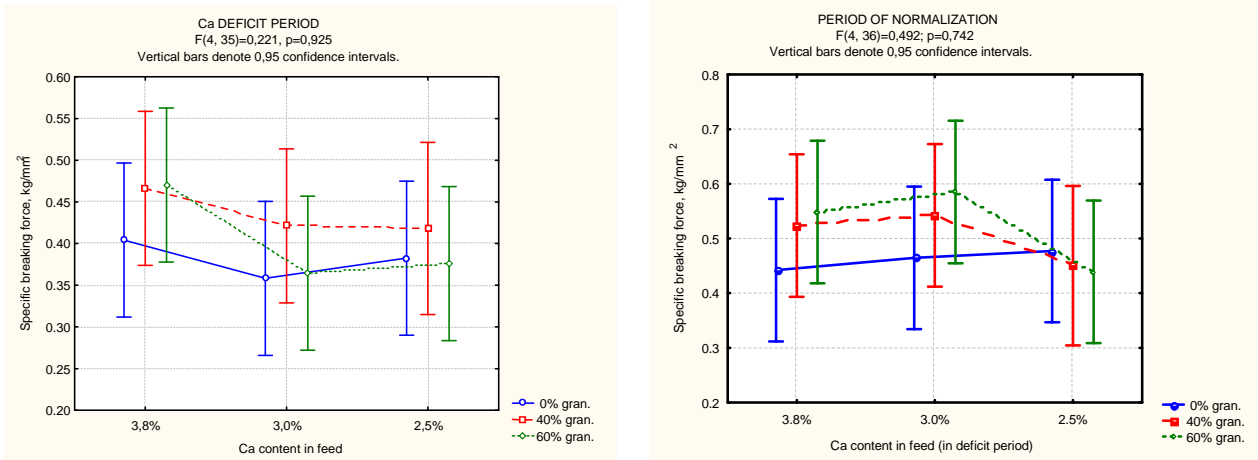

Graph 1. Average specific tibia breaking force in layers at the end of the period of deficit of Ca (left graph) and at the end of period of normalization of nutrition (right graph), $\mathrm{kg} / \mathrm{mm}^{2}$ 
Whitehead $(1999,2004)$ pointed out that dynamic processes in skeletal Ca depots during laying period in time can have adverse effect on bone firmness due to loss of the bone structure. The scope and duration of these changes in bone quality depend on numerous factors and can cause the incidence of osteoporosis in layers at the end of the laying period and consequently bone fractures, which has been serious problem with layers housed in cage system.

Excretion of $\mathrm{Ca}$, from the quantitative aspect, in layers primarily is associated with production of eggs. So, it can be assessed by measuring the egg quality, first of all of egg shell considering that the amount of calcium carbonate deposited in the egg shell, hence the egg shell quality, essentially is associated with the calcium metabolism and balance (Roland and Bryant, 2000; Roberts and Blaney, 2000; Roberts, 2004). In dry matter of the egg shell (without membranes) there is approx. $2 \%$ of organic matter, whereas the remaining are crystals of calcium carbonate in the form of calcite. Layer hen, through egg shell, excretes daily in average $2.0-2.5 \mathrm{~g}$ calcium depending on the egg mass.

Most of Ca necessary for forming of the egg shell is obtained directly from the digestive tract. However, if the limited amount of $\mathrm{Ca}$ is available from the intestines due to lower concentration in food or some other reasons, the Ca deriving from other sources will be used, primarily $\mathrm{Ca}$ deposited in bones, which can lead to decrease in the egg shell quality. Roland (1986a) finds that the ability of layers to deposit/store calcium for future forming of egg shell is limited, stating the fact that most layers have calcium reserves in bones sufficient for 4 to 5 eggs, but also the opinion that maximum egg shell quality cannot be maintained even for one day without $\mathrm{Ca}$ in diet, i.e. if only $\mathrm{Ca}$ deposited in bones is available to them.

Lukic (2008) has studied the effects of three Ca levels in feed (3.8; 3.0 and $2.5 \%)$ and 3 different ratios of powder and large particle Ca sources (100:0; 60:40 and 40:60\%) in diets for young layers, as well as the effects of three week normalization of their $\mathrm{Ca}$ nutrition subsequent to applied $\mathrm{Ca}$ deficit. Results indicated that $\mathrm{Ca}$ level and use of large marble particles in diet for layers mostly affected the traits of egg shell quality, and to some extent also the quality of bones of laying hens. Applied $\mathrm{Ca}$ deficit caused firstly lower incorporation of $\mathrm{Ca}$ in egg shell in quantitative sense, but also subsequent lower eggshell quality (Graph 2), and higher mobilization of calcium from bone deposits. Subsequent to normalization of nutrition with $\mathrm{Ca}$, young laying hens normalized the quality of eggs very fast.

The use of large marble particles in nutrition of young layers had positive effect on egg shell thickness and its quality expressed by breaking force (Graph 3). 

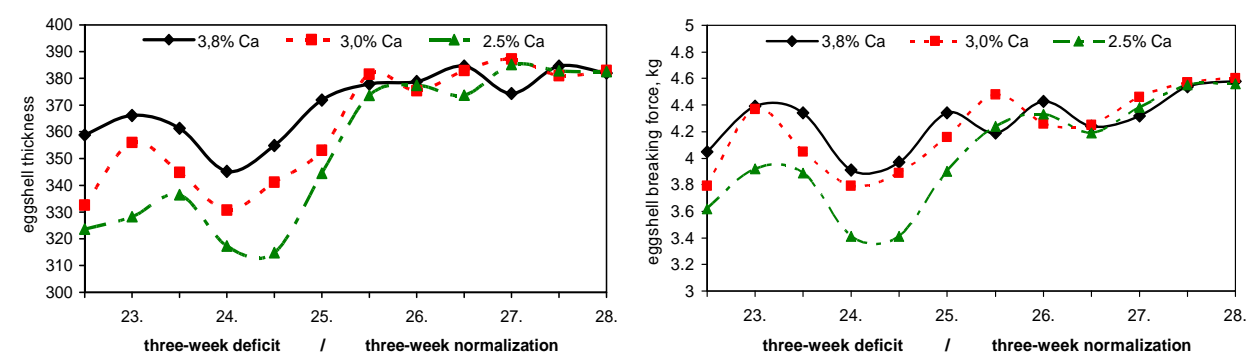

Graph 2. Variation of the egg shell thickness in $\mu \mathrm{m}$ (left graph) and eggshell breaking force (right graph) depending on the Ca content in feed
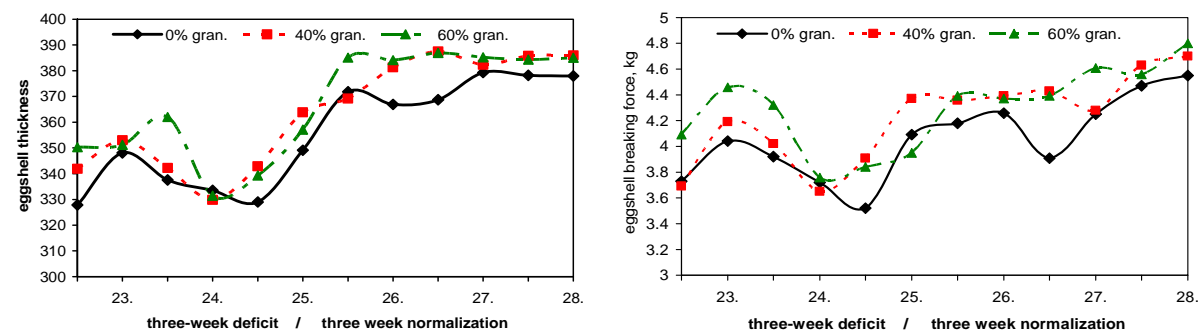

Graph 3. Variation of the egg shell thickness in $\mu \mathrm{m}$ (left graph) and eggshell breaking force (right graph) depending on the share of large size marble particles (\% of granulated $\mathrm{Ca}$ ) in feed

Roberts and Blaney (2000), in their research of the traditional egg shell quality parameters, but also in their study of the changes in the fine structure (ultra structure) of egg shell under the microscope, reported that the use of diet with low Ca level caused significant reduction of all traditional egg shell quality parameters (egg shell mass, percentage, egg shell thickness), whereas, contrary to them, the ultra structure of the egg shell changed in the direction of increase of the egg shell firmness, suggesting that decrease of the amount of egg shell is probably to certain extent compensated by increase of the quality of its construction.

Hunton (2005), pointed out the practical aspect of the egg shell quality, stating the fact that in commercial egg production egg shell represents perfect package which provides protection from mechanical damage and contamination of the egg content, and that defects of egg shell have significant economical effect in a way that they reduce the value of the egg. Stadelman (1994) states the assessment that the lowest egg shell thickness necessary is $0.33 \mathrm{~mm}$ in order for an egg to have over $50 \%$ chance to go through the normal market chain without being broken. Carnarius et al. (1996) have studied the egg shell thickness of broken eggs, eggs with damaged egg shell and eggs with good egg shell and established that the thickness of egg shell of good quality was $0.38 \mathrm{~mm}$. Pavlovski and Vitorović 
(1996), in the study describing the new instrument/apparatus and first results of the measuring of egg shell breaking force, stated that the average egg of optimal egg shell quality has firmness of approx. $4 \mathrm{~kg}$ and thickness of approx. $0.375 \mathrm{~mm}$.

In general, it can be concluded that variations of any of mentioned and considered factors which influence the Ca metabolism and balance in laying hens also demonstrate an effect on quality of layer bones and egg shell. Also, the balance of all other nutrients in diet for layers important for $\mathrm{Ca}$ metabolism, primarily of vitamin $\mathrm{D}$, phosphorus and certain micro elements, is important because of the mutual interaction relation (Lukić et al., 2009a). Vitamin D is important for $\mathrm{Ca}$ absorption, as well as its mobilization from bones, hence for production of eggs, forming of egg shell and normal homeostasis of calcium in layers (Soares, 1984; Ameenuddin et al., 1985; Boruta et al., 2007). Together with $\mathrm{Ca}$, phosphorus is the most important integral component of the bones. Its deficiency reduces the bone mineralization and increases the urinary excretion of $\mathrm{Ca}$, whereas the high level in blood inhibits the mobilization of calcium from bones (Roland, 1986a; Coelho, 2001). Manganese and zinc are also active participants in $\mathrm{Ca}$ metabolism, i.e. process of egg shell forming. If not properly balanced in the diet for layers, they can diminish the quality of egg shell (Gomez-Basauri, 1998; Ceylan et al., 2000).

\section{Calcium requirements of layers}

Calcium requirements which ensure high laying ability, good egg shell quality and good animal health have been a topic of many studies and revisions for many years. Standing goal of the multi-decade work is more precise meeting of the requirements of new hybrids with higher genetic production potential, as well as solving of issues that have constantly been in the focus of attention - egg shell quality and bone quality of layers during their exploitation.

Roland (1986a), summarizing in the study their previous researches of the $\mathrm{Ca}$ requirements of Leghorn type layers for maximum production and egg shell quality (from 1942 to 1984), pointed out that high variations in results obtained by different researchers demonstrated how difficult it was to determine the $\mathrm{Ca}$ requirements of layers. In spite of great variations, based on the average for results obtained by researchers over decades of observation, a constant increase of $\mathrm{Ca}$ requirements over time was registered (by $0.70 \mathrm{~g} / \mathrm{layer} / \mathrm{day}$ during the sixties compared to previous period, i.e. 0.29 during the seventies and 0.53 during the eighties), whereas, at the same time, a tendency of slight decrease of $\mathrm{P}$ requirements was recorded. This trend continued in the recent researches. Leeson (2006) summarizing in his study recommendations based on many years of research done at the University Guelp from Canada, pointed out that in diets for layers in 2005 double amount of Ca was necessary compared to diets for layers 50 years ago (2.1\% in year 1956 compared to $4.0 \%$ in 2005$)$. 
In practice, the requirements are expressed in form of recommendations for dietary level necessary to ensure meeting of all requirements and need of layers, however these recommendations can be different in different countries, and also depend on energy content of the diet and animal, consumption and digestibility of the food. Usually, in designing the nutrition program and diets for layers, but also as starting point in revisions, the latest recommendations given by the American NRC, European AEC recommendations, technological recommendations of the producers of layer hybrids, as well as national regulations on the quality of animal food are taken into consideration.

Adequacy of the recommended quantities of dietary $\mathrm{Ca}$ for layers is still being studied. Castillo et al. (2004), perceiving the valid NRC recommendations (1994) contradictory, carried out a research establishing the effect of 5 levels of Ca (from $2.93 \%$ to $4.82 \%$ ) on production and quality of egg shell in a modern layer hybrid -white eggs, to determine the biologically optimal level to realize maximum production and egg shell quality. Based on research results, the authors reported that under given conditions, biologically optimal level of Ca necessary to realize the maximum production was $4.38 \%$, for maximum egg shell quality $4.64 \%$, and economically optimal level for maximum profit was $4.35 \%$ of $\mathrm{Ca}$ in diet.

Many researchers in their studies start with the assumption which is becoming scientific proven fact, that the adequate $\mathrm{Ca}$ nutrition of laying hens does not include only the adequate level of $\mathrm{Ca}$ in diet, but also adequate source and particle size of Ca. Namely, it is considered that larger particles of $\mathrm{Ca}$ source are retained longer in the gizzard and are slowly being degraded and absorbed during this longer passage through digestive tract, whereas the smaller Ca particles pass faster through the digestive tract and therefore they get degraded/absorbed partially (Scott et al.,1971; Roland, 1986b; Zhang and Coon, 1997; Svihus, 2011). In many researches different sources and particle sizes have been compared, as well as shares of fine and coarse particles in the diet, when and how they are added to the diet, in order to determine optimal solutions. Among others, Lukić et al. (2009b) find that the use of $40-60 \%$ of coarsely ground marble from the beginning of laying justified. Vitorović et al. (2004) pointed out that by substituting 60 to $80 \%$ of lime with large size lime particles in mixtures for nutrition of older layers, positive effects on the egg shell quality can be realized, and Pavlovski et al. (2008) stated that by using coarsely ground marble in nutrition of layers the adverse effect of suboptimal level of dietary $\mathrm{Ca}$ can be alleviated to some extent.

In future researches dealing with the adequate nutrition of layers with calcium, complex studies which consider not only calcium, but also other nutrients and factors and their mutual relation, will become increasingly important. So, Keshavarz (2003), has studied in two experiments individual and mutual effect of different levels of dietary $\mathrm{Ca}(3.34 ; 4.3 ; 4.73$ and $4.94 \%)$ and different sources of vitamin $\mathrm{D}$ (vitamin $\mathrm{D}_{3}$ and $25-\mathrm{OH}-\mathrm{D}_{3}$ ), i.e. in the second experiment different levels of phosphorus $(0.11 ; 0.21$ and $0.41 \%)$, presence of phytase $(0$ and $300 \mathrm{U} / \mathrm{kg}$ 
of diet) and different sources of vitamin $\mathrm{D}$ (vitamin $\mathrm{D}_{3}$ and 25-OH- $\mathrm{D}_{3}$ ) in diet for layers on the production traits and egg shell quality. Among other things, author concluded that the level of dietary $\mathrm{Ca}$ of $3.34 \%$, that provided $3.63 \mathrm{~g}$ Ca per layer daily based on realized consumption, , was adequate for production and egg shell quality. Also, used level of non-phytate phosphorus of $0.21 \%$ was adequate value, whereas the application of the phytase enzyme had no effect on production results, but did demonstrate effect on parameters of egg shell quality, and substitution of vitamin D with $25-\mathrm{OH}-\mathrm{D}_{3}$ had no effect in any of the trials in given conditions. Similar to previous study, Huyghebaert and Maertens (2007) investigated the effect of different combinations of 2 forms of vitamin D (vitamin $\mathrm{D}_{3}$ and 25-OH$\mathrm{D}_{3}$ ) and 3 combinations of $\mathrm{Ca}$ and $\mathrm{P}$ concentrations (normal $\mathrm{Ca} /$ normal $\mathrm{P}$, low $\mathrm{Ca}$ /normal $\mathrm{P}$ and low $\mathrm{Ca} /$ low $\mathrm{P}$ ) in diets for layers on production characteristics, egg shell quality and tibia properties. The authors reported that in young layers (2044 weeks of age) low level of $\mathrm{Ca}$ in diets $(3.1 \% \mathrm{Ca})$ caused significant decrease in egg mass and observed egg shell quality properties, as well as increased incidence of damaged (cracked) eggs, and that adding of active form of vitamin into diet showed tendency of compensation of the adverse effect of low Ca level on egg shell quality.

However, Leeson (2006) anticipates that the ecological requirements and legislation will have to be more considered in the future in determination of the dietary $\mathrm{Ca}$ since they regulate and limit the excretion and presence of $\mathrm{P}$ in the manure (as well as nitrogen and some micro elements, such as zinc and copper) which is achieved by use of chelate forms of micro element sources, by lowering of the dietary phosphorus and/or adding of phytase enzyme (Balander, 1998; Lukić, 2001), and this requires adequate level of dietary $\mathrm{Ca}$ due to mutual interaction of minerals.

\section{Adequate calcium nutrition - changes in the practice}

Conventional approach in the practice, when meeting the calcium requirements of layers of table eggs, is to apply relatively same recommendations in the design of a nutrition program and diets for layers, and usually recommended percentage of $\mathrm{Ca}$ in diet is applied without taking into consideration the concrete diet and concrete production conditions. However, if we want to ensure for high productive layer proveniences precise and complete $\mathrm{Ca}$ requirements, we must know and consider series of factors which are characterizing the production, when formulating the diet. Main factors which influence adequate determination of layers' needs and requirements are: permanent genetic progress of layers, mutual dependence between calcium and other nutrients, the effect of Ca particle size as well as the fact that layers' Ca requirements in practice are expressed as its $\%$ in the diet, not taking into consideration the variations in food consumption 
(variations as result of energy level, environment temperature, various layer proveniences and/or age of poultry).

Typical nutrition of contemporary layer hybrids used in production of table eggs includes the nutrition program for rearing period and production period in order to meet the animal requirements for growth, development and production, as precise as possible (Jokić et al., 2004), where each producer of hybrids prescribe in their technological manuals framework nutrition program adequate to characteristics of the given hybrid. Also, preparation of each diet has to be carefully planned and considering all major factors (environment temperature, floor or cage production system, control of body mass, daily consumption and production of layers) and adjusted to meeting of all requirements of the flock, especially at the beginning of the laying period.

In practice, quantitative and qualitative effect of as much as possible these factors on concrete production should be considered and on that basis should be chosen not only adequate level of dietary $\mathrm{Ca}$, but also adequate source and particle size of added $\mathrm{Ca}$, and also mutual balance with other nutrients in the diet balances, especially with vitamin D, phosphorus and certain micro elements (Coelho, 2001; Lukić et al., 2009a). Also, based on scientific proven facts, it is necessary to implement more in practice the possibility to increase the availability of phytine bound phosphorus and calcium by using the phytase enzyme and consider further revisions of recommendations regarding the available phosphorus. It is important to monitor scientific results of unbiased studies of new vitamin D sources and chelated micro elements, researches that have become very popular in recent years and resulted in some new commercial products on the market, but only based on actual results obtained in practice it will be possible to assess the possibility and economical justification of their use and use of other additives in food for layers.

\section{Conclusion}

Formulating of complete and well balanced mixtures for laying hens in regard to calcium is a complex and responsible task, of which it will greatly depend to which extent the modern poultry hybrids will be able to demonstrate their genetic potential on production farms, in regard to quantity and quality of eggs, as well as preservation of health and vitality. In order to be successful in this task, and provide $\mathrm{Ca}$ nutrition of layers which would follow their constant genetic progress and prevent metabolic disorders manifested by poor egg shell quality and bone quality, practice must adjust faster and more consistent with new scientific findings. 


\title{
Acknowledgment
}

Research was part of the project TR 31033 financed by the Ministry of Education and Science, Republic of Serbia.

\section{Adekvatna ishrana kalcijumom i kvalitet ljuske i kostiju kod nosilja - inovirani pristup problemu}

\author{
M. Lukić, Z. Pavlovski, Z. Škrbić
}

\section{Rezime}

Metabolizam kalcijuma (Ca) kod nosilja zavisi od niza faktora koji se mogu podeliti na one koji utiču na unos, usvajanje, zadržavanje i/ili izlučivanje Ca. Varijacije bilo kojeg od ovih, u radu predstavljenih i razmotrenih faktora, ispoljavaju svoj uticaj i na kvalitet kostiju i ljuske jaja nosilja. Radi očuvanja kvaliteta jaja i kostiju nosilja, u praksi treba uzeti u obzir uticaj ovih faktora na konkretnu proizvodnju i na bazi toga odrediti ne samo adekvatan obročni nivo $\mathrm{Ca}$, već i odgovarajući izvor i veličinu čestica dodatog $\mathrm{Ca}$, kao i međusobni balans sa ostalim nutrijentima $\mathrm{u}$ obroku, pre svega fosforom, vitaminom D i nekim mikroelementima. Nova istraživanja idu u pravcu kompleksnijeg pristupa pri rešavanju problema sa kvalitetom ljuske jaja i kostiju i adekvatnom ishranom savremenih hibridnih nosilja.

\section{References}

AMEENUDDIN S., SUNDE M.L., COOK M.E. (1985): Essentiality of vitamin $\mathrm{D}_{3}$ and its metabolites in poultry nutrition: a review. World's Poultry Science Journal, 41, 52-63.

BALANDER R. (1998): Egg production and egg specific gravity in laying hens fed reduced phosphorus diets supplemented with phytase. In: Biotechnology in the Feed Industry, Proceedings of Alltech's Fourteenth Annual Symposium (Edited by T.P. Lyons and K.A. Jacques), Nottingham University Press, Nottingham, U.K., 411-419.

BORUTA A., KOPOWSKI J., MAJEWSKA A. (2007): Effect of active form of vitamin $\mathrm{D}_{3}$ and phytobiotic on shell quality of laying hens. XVIII European Symposium on the Quality of Poultry Meat and XII European Symposium on the Quality of Eggs and Egg Products, Prague, September 2-5, Symposium Proceedings, 206-207. 
CARNARIUS K.M., CONRAD K.M., MAST M.G., MACNEIL J.H. (1996): Relationship of eggshell ultrastructure and shell strength to the soundness of shell eggs. Poultry Science, 75, 656-664.

CASTILlO C., CUCA M., PRO A., GONZALEZ M., MORALES E. (2004): Biological and economic optimum level of calcium in White Leghorn laying hens. Poultry Science, 83, 868-872.

CEYLAN N., SCHEIDELER S.E., SEFTON T. (2000): Effects of calcium level and chelated $\mathrm{Mn}$ and $\mathrm{Zn}$ on performance and egg quality in layers at different lay period. XXI World's Poultry Congress, Montreal, Canada, 20-24 August 2000 (Abstracts \& Proceedings CD).

COELHO M. (2001): Involvement of calcium and phosphorus in bone and shell quality of early maturing commercial layers. World Poultry, 17, 6, 16-19.

GOMEZ-BASAURI J. (1998): Egg shell quality: overcoming production losses with a novel enzyme activator. In: Biotechnology in the Feed Industry, Proceedings of Alltech's Fourteenth Annual Symposium (Edited by T.P. Lyons and K.A. Jacques), Nottingham University Press, Nottingham, U.K., 437-445.

HUNTON P. (2001): Calcium sources for laying hens. Factsheet\#133. Internet http://www.poultryindustrycouncil.ca/factsheets/fs_133.pdf

HUNTON P. (2005): Research on eggshell structure and quality: an historical overview. Brazilian Journal of Poultry Science, 7, 2, 67-71.

HURWITZ S., BAR A. (1965): Absorption of calcium and phosphorus along the gastrointestinal tract of the laying fowl as influenced by dietary calcium and egg shell formation. Journal of Nutrition, 86, 433-438.

HUYGHEBAERT G., MAERTENS L. (2007): The efficacy of 25-OHcholecalciferol in combination with different dietary Ca-P concentrations for laying hens. Proceedings $16^{\text {th }}$ European Symposium on Poultry Nutrition, Strasbourg, France, August 26-30, 2007, 701-704 (CD-ROM).

JOKIĆ Ž., KOVČIN S., JOKSIMOVIĆ-TODOROVIĆ M. (2004): Ishrana živine. Poljoprivredni fakultet, Beograd.

KESHAVARZ, K. (2003): A comparison between cholecalciferol and 25-OHcholecalciferol on performance and eggshell quality of hens fed different levels of calcium and phosphorus. Poultry Science, 82, 1415-1422.

LEACH R.M. (2000): Physiology of bone growth and development. XXI World's Poultry Congress, Montreal, Canada, 20-24 August 2000 (Abstracts \& Proceedings $\mathrm{CD})$.

LEESON S. (2006): Defining and predicting changes in nutrient requirements of poultry. World's Poultry Science Journal, 62, (Abstracts \& Proceedings CD).

LUKIĆ M. (2001): Uticaj fitaze $\mathrm{u}$ ishrani brojlera na proizvodne rezultate $\mathrm{i}$ zdravstveno stanje. Magistarska teza, Fakultet veterinarske medicine, Beograd.

LUKIĆ M. (2008): Uticaj deficita kalcijuma i udela krupnih čestica mermera u ishrani na proizvodne rezultate, kvalitet jaja i kostiju kokoši nosilja. Doktorska disertacija, Poljoprivredni fakultet, Beograd. 
LUKIĆ M., PAVLOVSKI Z., ŠKRBIĆ Z, JOKIĆ Ž., PETRIČEVIĆ V. (2009b): Possibility of preventing short term calcium deficit by using large size marble particles in nutrition of young laying hens. Archiva Zootechnica, 12, 4, 22-36. LUKIĆ M., PAVLOVSKI Z., ŚKRBIĆ Z. (2009a): Mineral nutrition of modern poultry genotypes. Biotechnology in Animal Husbandry, 25, 5-6, Book 1, 399-409. LUKIĆ M., PAVLOVSKI Z., ŠKRBIĆ Z., PETRIČEVIĆ V., VITOROVIĆ D., JOKIĆ Ž. (2010): Effect of marble particles and calcium level in nutrition of young layers on quality of eggs and bones. Proceedings (CD) of XIII European Poultry Conference, Tours, France, 23-27. August. CD of proceedings, EISSN numbers 1743-4777, http://epc2010.org/cd/index.html

PAVLOVSKI Z., LUKIĆ M., ŠKRBIĆ Z., BLAGOJEVIĆ M. (2008): Efficiency of the use of large size marble particles in conditions of three week calcium deficit in young layer hens. $1^{\text {st }}$ Mediterranean Summit of WPSA "Advances and Challenges in Poultry Science", 7-10. May 2008, Porto Carras, Greece. Book of Proceedings, 852-857.

PAVLOVSKI Z., VITOROVIĆ D. (1996): Direktan metod za određivanje čvrstoće ljuske jaja. Nauka u živinarstvu, 3-4, 171-175.

REID B.L., WEBER C.W. (1976): Calcium availability and trace mineral composition of feed grade calcium supplements. Poultry Science, 55, 600-605.

ROBERTS J.R. (2004): Factors affecting egg internal quality and egg shell quality in laying hens. Journal of Poultry Science, 41, 161-177.

ROBERTS J.R., BLANEY C.E. (2000): Egg shell ultrastructure and shell quality. Relation of ultrastructure to egg shell quality and strength. XXI World's Poultry Congress, Montreal, Canada, 20-24 August 2000 (Abstract \& Proceedings CD).

ROLAND D.A. (1986a): Egg shell quality III: Calcium and phosphorus requirements of commercial Leghorns. World's Poultry Science Journal, 42, 154-165. ROLAND D.A. (1986b): Eggshell quality IV: Oystershell versus limestone and the importance of particle size or solubility of calcium source. World's Poultry Science Journal, 42, 166-171.

ROLAND D.A., BRYANT M. (2000): Nutrition and feeding for optimum egg shell quality. XXI World's Poultry Congress, Montreal, Canada, 20-24 August 2000 (Abstracts \& Proceedings CD).

ROLAND D.A., SLOAN D.R., HARMS R.H. (1972): Calcium metabolism in the laying hen. 1. Calcium retention in the digestive tract of the laying hen. Poultry Science, 51, 598-601.

SCOTT M.L., HULL S.J., MULLENDORF P.A. (1971): The calcium requirements of laying hens and effects of dietary oyster shell upon egg shell quality. Poultry Science, 50, 1055-1063.

SILVERSIDES F.G., KORVER D.R., BUDGELL K.L. (2006): Effect of strain of layer and age at photostimulation on egg production, egg quality and bone strength. Poultry Science, 85, 1136-1144. 
SOARES J.H. (1984): Calcium metabolism and its control - a review. Poultry Science, 63, 2075-2083.

STADELMAN W.J. (1994): Quality identification of shell eggs. In: WILLIAM J., STADELMAN I., QEEN J., COTTERILL (eds), Egg science and technology, 4th edition. Food Products Press, Imprint of The Haworth Press, Inc., New York London, 39-67.

SVIHUS B. (2011): The gizzard: function, influence of diet structure and effects on nutrient availability. World's Poultry Science Journal, 67, 2, 207-223.

TAHER A.I., GLEAVES E.V., BECK M. (1984): Special calcium appetite in laying hens. Poultry Science, 63, 2261-2267.

VITOROVIĆ D., PAVLOVSKI Z., ŠKRBIĆ Z., LUKIĆ M., ADAMOVIĆ I. (2004): Čvrstoća ljuske jaja. Biotehnologija u stočarstvu, 20, 3-4, 107-111.

WHITEHEAD C.C. (1999): Reducing osteoporosis in laying hens. World Poultry, $15,9,78-82$.

WHITEHEAD C.C. (2004): Overview of bone biology in the egg-laying hen. Poultry Science, 83, 193-199.

ZHANG B., COON C. (1997): The relationship of calcium intake, source, size, solubility in vitro and in vivo, and gizzard limestone retention in laying hens. Poultry Science, 76, 1702-1706. 